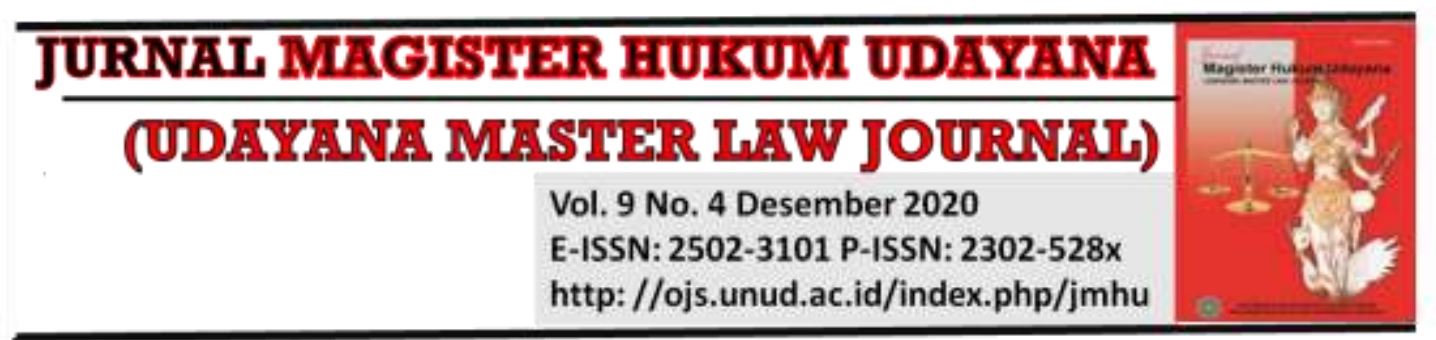

\title{
Pengaturan Lembaga Penjamin Polis pada Perusahaan Asuransi di Indonesia
}

\author{
Ni Putu Sintha Tjiri Pradnya Dewi ${ }^{1}$, Desak Putu Dewi Kasih ${ }^{2}$ \\ ${ }^{1}$ Made Rai Sugupta Law Office, E-mail: sinthatjiri@gmail.com \\ ${ }^{2}$ Fakultas Hukum Universitas Udayana, E-mail: dewi_kasih@unud.ac.id
}

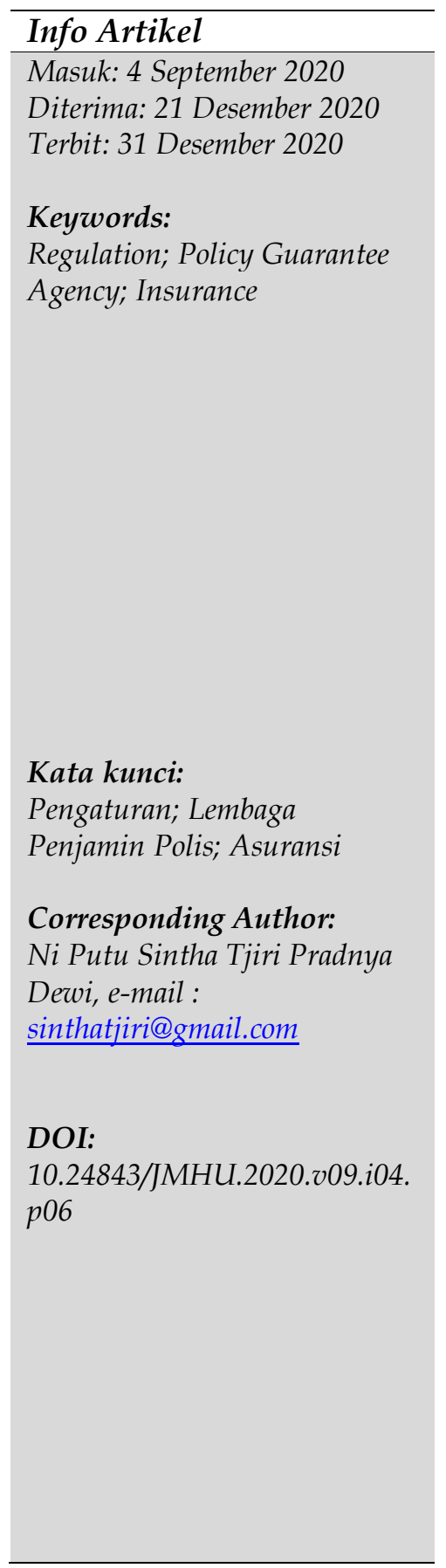

\begin{abstract}
This study aims to analyze the policy underwriting organization arrangements in insurance companies in Indonesia and the absence of a policy guarantor institution at insurance companies in Indonesia. The method used in research related to the regulation of policy insurance institutions in insurance companies in Indonesia uses normative juridical legal research. This study uses a statutory approach or statute approach to analyze legal issues in this study. Sources of legal materials in this study consist of primary legal materials, secondary legal materials, and also tertiary legal materials. The results of this study found that the insurance company has not regulated the policy guarantor in Indonesia in positive law in Indonesia even though it has been mandated in Law Number 40 of 2014 concerning Insurance. The absence of regulations regarding policy underwriters in insurance companies in Indonesia has resulted in public distrust of insurance companies, so it is necessary to regulate policies related to insurance companies in insurance companies in Indonesia.
\end{abstract}

Abstrak
Penelitian ini bertujuan untuk menganalisis pengaturan
lembaga penjamin polis pada perusahaan asuransi di Indonesia
serta tidak adanya lembaga penjamin polis pada perusahaan
asuransi di Indonesia. Metode yang digunakan dalam penelitian
terkait pengaturan lembaga penjamin polis pada perusahaan
asuransi di Indonesia ini menggunakan jenis penelitian hukum
yuridis normatif. Penelitian ini menggunakan pendekatan
perundang-undangan atau statute approach untuk menganalisis
isu hukum dalam penelitian ini. Sumber bahan hukum dalam
penelitian ini terdiri dari bahan hukum primer, bahan hukum
sekunder, dan juga bahan hukum tersier. Hasil dari penelitian ini
menemukan bahwa belum diaturnya lembaga penjamin polis
pada perusahaan asuransi di Indonesia dalam hukum positif di
Indonesia walaupun telah diamanatkan dalam Undang-Undang
Nomor 40 tahun 2014 tentang Perasuransian. Tidak adanya
pengaturan terkait lembaga penjamin polis pada perusahaan
asuransi di Indonesia mengakibatkan ketidakpercayaan
masyarakat terhadap perusahaan asuransi, sehingga perlu
pengaturan terkait lembaga penjamin polis pada perusahaan
asuransi di Indonesia.




\section{Pendahuluan}

Asuransi dalam sejarahnya sangat penting bagi seluruh manusia guna memperkecil risiko yang timbul dari ketidakpastian dengan mengalihkan atau membagi risiko yang menjadi ancaman bagi mereka, antar satu pihak dengan pihak yang lain. ${ }^{1}$ Di lain sisi asuransi merupakan sejarah pada kehidupan manusia dalam mengambil keuntungan dengan pengumpulan dana dari masyarakat melalui pemberian janji untuk memberikan manfaat pada pihak yang berkeinginan menjauhi diri dari ancaman risiko yang muncul karena ketidakpastian. ${ }^{2}$ Aktivitas asuransi ada di Indonesia akibat pengaruh dari keberhasilan Belanda dalam usaha perdagangan dan perkebunan di negara jajahannya. ${ }^{3}$ Mulanya, aktivitas asuransi hanya untuk memberikan perlindungan keperluan Belanda, Inggris, serta bangsa Eropa lain yang melakukan usaha perkebunan dan perdagangan di Indonesia, khususnya mengenai asuransi kebakaran dan pengangkutan. ${ }^{4}$

Dewasa ini asuransi telah menjadi kebutuhan penting karena akan memberikan kenyamanan dan rasa terlindungi pada kemungkinan yang akan terjadi dari risiko kerugian pada kemudian hari. Asuransi dapat dikatakan sebagai transfer adil terhadap risiko dari suatu kerugian, dari entitas satu ke lain entitas melalui pembagian risiko dengan pembayaran pada sejumlah premi. ${ }^{5}$ Asuransi memberi pertanggungan atau perlindungan terhadap objek pada aktivitas yang kemungkinan menyebabkan kerugian. ${ }^{6}$ Perusahaan yang melakukan pengalihan risiko berdasarkan perjanjian asuransi dapat meningkatkan usaha serta dapat menggalang tujuan yang lebih besar. ${ }^{7}$ Begitu juga dengan premi yang terkumpul dapat diupayakan dan dipergunakan sebagai sarana pengembangan perusahaan di bidang asuransi itu untuk terus menjaga kepecayaan nasabah yang selanjutnya hasil tersebut dapat dinikmati oleh nasabah itu kembali. ${ }^{8}$

Asuransi pada dasarnya memiliki beberapa manfaat, yaitu yang pertama memberikan bantuan bagi masyarakat untuk menyelesaikan berbagai macam permasalahan risiko yang dijalaninya, dengan demikian akan memberi kepercayaan diri serta ketenangan yang lebih bagi para pihak yang bergabung dalam asuransi. Kedua sebagai sarana dalam menyelesaikan berbagai risiko yang dijalani ketika melakukan pembangunan. Lain daripada itu, meskipun ada berbagai cara untuk menghadapi risiko, selanjutnya asuransi menjadi cara yang lebih sering dipergunakan hal itu karena asuransi memberikan janji pertanggungan pada pihak tertanggung risiko yang akan dijalani secara personal ataupun risiko yang akan dijalani oleh lembaga asuransi.

1 Ganie, A. Junaedy. (2011). Hukum Asuransi Indonesia. Jakarta: Sinar Grafika, h. 31.

2 Ibid.

3 Ibid, h. 34.

4 Ibid.

5 Ibid.

6 Wasita, A. (2020). Perlindungan Hukum Terhadap Pemegang Polis Asuransi Jiwa. Business Economic, Communication, and Social Sciences (BECOSS) Journal, 2(1), 105-113.

${ }^{7}$ Hengky KV, P. (2013). Perlindungan Pemegang Polis Pada Asuransi Jiwa Di Kaitkan Dengan Nilai Investasi. Jurnal Hukum Unsrat, 1(6), 1.

8 Ibid. 
Perkembangan asuransi semakin lama semakin menunjukkan perubahan yang cukup pesat. 9 Berbagai perusahaan yang berada pada bidang jasa asuransi memberi penawaran produk-produk dari asuransi, dari jasa asuransi jiwa, asuransi kerugian, asuransi tenaga kerja, asuransi kesehatan, serta jenis asuransi lainnya hingga pada asuransi dengan tabungan yang menjadi unsurnya, contohnya asuransi jiwa unit link..$^{10}$ Perusahaan asuransi era ini dibagi menjadi cabang-cabang. Jenis-jenis dari seluruh pembagian yaitu asuransi pemerintah dan asuransi swasta. ${ }^{11}$ Cakupan aktivitas asuransi yang luas tentu saja mempengaruhi peningkatan jumlah pemegang polis di Indonesia. Di tambah lagi dewasa ini banyak lembaga asuransi bersaing untuk memberikan penawaran berbagai jenis produk asuransi yang bertujuan mengajak masyarakat untuk bergabung dalam memiliki asuransi. ${ }^{12}$ Banyaknya produk yang perusahaan asuransi tawarkan tidak sebanding dengan jaminan yang diberikan bagi pemegang polis asuransi dari sisi perlindungan hukum. Masalah yang sering terjadi yaitu sulitnya mendapatkan pembayaran ganti kerugian bagi pemegang polis saat terjadi evenement. Hal tersebut tidak selaras dengan tujuan utama seorang pemegang polis ataupun nasabah yaitu untuk menerima kompensasi apabila terjadi suatu peristiwa yang tidak terduga pada objek asuransi. ${ }^{13}$

Salah satu contohnya adalah munculnya Covid-19 yang sudah disahkan sebagai pandemi global berdasarkan World Health Organization. Peristiwa ini sangat tidak terduga dan virus tersebut menyebar cepat dan masif. Industri asuransi jiwa telah mencatat perkembangan tertanggung yang jumlahnya mencapai 10,8 juta orang dalam satu tahun terakhir, akan tetapi terjadinya penurunan jumlah premi sebesar 2,3 triliun rupiah hingga maret 2020.14

Sebagian besar perusahaan asuransi di Indonesia melakukan reasuransi yaitu membagi resiko yang dihadapinya dengan mengasuransikan kembali sebagian nilai itu pada perusahaan reasuransi. Dengan adanya reasuransi tersebut, belum dirasa cukup untuk menjamin nasabah mendapatkan pertanggungan sepenuhnya dari perusahaan asuransi karena apabila perusahaan asuransi mengalami pailit maka perusahaan reasuransi hanya mengeluarkan 30\% dari biaya pertanggungan yang tertera di polis nasabah. ${ }^{15}$ Berdasarkan hal tersebut maka lembaga penjamin polis dinilai sangat penting di tengah banyaknya penurunan pendapatan premi ${ }^{16}$

${ }^{9}$ Riau, J. I. H. Pemegang Polis Asuransi dan Kedudukan Hukumnya. Jurnal Ilmu Hukum Riau, 2(02), hal. 2.

${ }_{10}^{10}$ Ibid.

${ }^{11} \mathrm{Ibid}$, hal 5.

${ }^{12} \mathrm{Ibid}$, hal. 5.

${ }^{13}$ Pratama, A. A., \& Bambang Eko Turisno, S. (2017). Perlindungan Hukum Bagi Konsumen Terhadap Perjanjian Perpanjangan Asuransi Melalui Telemarketing. Diponegoro Law Journal, 6(1), 1-21.

14 Pratama,Wibi P.https://finansial.bisnis.com/read/20200625/215/1257785/pandemi-covid19-jumlah-tertanggung-naik-kinerja-bisnis-asuransi-tertekan.(Diakses Selasa, 11 Agustus 2020).

${ }^{15}$ Asuransi, Aca. https://www.aca.co.id/Berita-Detail/Apa-sih-Reasuransi-itu (Diakses Jumat 18 Agustus 2020).

16 Pratama, Wibi P. https://finansial.bisnis.com/read/20200713/215/1265044/ruu-lembagapenjamin-polis-masuk-renstra-kementerian-keuangan-2020-2024. (Diakses Selasa, 11 Agustus 2020). 
Penelitian ini akan membahas 2 (dua) hal yaitu, pertama bagaimanakah pengaturan lembaga penjamin polis pada perusahaan asuransi di Indonesia? Kedua bagaimanakah dampak tidak adanya lembaga penjamin polis pada perusahaan asuransi di Indonesia?

Penelitian ini adalah karya ilmiah asli yang memiliki harapan untuk dapat berkontribusi dan berperan terhadap penambahan ataupun pengembangan ilmu pengetahuan. Beberapa studi terdahulu yang telah mengkaji mengenai asuransi diantaranya pertama, ditemukan pada Jurnal Hukum Universitas Sam Ratulangi berjudul Perlindungan Pemegang Polis Pada Asuransi Jiwa dikaitkan dengan Nilai Investasi yang menjelaskan tentang segala hak pemegang polis pada perjanjian asuransi, peraturan khusus yang berisi mengenai adanya hubungan antara perlindungan dana investasi dan asuransi jiwa, serta pelaksanaan dari perlindungan hukum bagi nasabah pada asuransi dalam prakteknya di Indonesia. ${ }^{17}$ Kedua, ditemukan pada Jurnal Kertha Semaya Universitas Udayana berjudul Kedudukan Hukum Pemegang Polis Pada Perusahaan Asuransi yang Dinyatakan Pailit yang menjelaskan mengenai perlindungan bagi pemegang polis dalam sisi hukum pada pailitnya suatu perusahaan asuransi serta akibat secara hukum yang ditimbulkan dari pailitnya perusahaan asuransi bagi pemegang polis. ${ }^{18}$ Ketiga yaitu Jurnal Hukum Bisnis Universitas Narotama Surabaya berjudul Perlindungan Hukum Pembeli Polis Asuransi Online yang menjelaskan mengenai perlindungan yang diberikan terhadap tertanggung secara hukum yang menutup perjanjian asuransi secara online serta perjanjian Otoritas Jasa Keuangan terhadap pengawasan asuransi online. ${ }^{19}$

Penelitian ini memiliki tujuan untuk melakukan analisis pengaturan lembaga penjamin polis pada perusahaan asuransi di Indonesia dan mengetahui dampak dari tidak adanya lembaga penjamin polis pada perusahaan asuransi di Indonesia.

\section{Metode Penelitian}

Penulisan karya ilmiah tentang pengaturan lembaga penjamin polis bagi perusahaan asuransi di Indonesia menggunakan jenis penelitian hukum yuridis normatif. Penelitian yuridis normatif adalah suatu penelitian yang berfokus terhadap analisis bahan hukum berupa segala jenis peraturan yang berlaku di Indonesia sebagai bahan acuan utama dalam penelitian tersebut. ${ }^{20}$ Suatu penelitian hukum yuridis normatif dapat pula dikatakan sebagai suatu prosedur penelitian yang menggunakan logika ilmu hukum dari sudut pandang normatif untuk menemukan kebenaran, hal tersebut kemudian mampu menjelaskan pengaturan dari lembaga penjamin polis bagi perusahaan asuransi di Indonesia. Penelitian ini mempergunakan statute approach (pendekatan peraturan perundang-undangan) dalam mengkaji permasalahan pada penelitian ini. Sumber bahan hukum yang digunakan yaitu bahan hukum primer, sekunder, dan juga tersier. Penelitian ini memiliki sifat deskriptif analisis yaitu memberikan gambaran terhadap permasalahan yang dibahas penelitian ini serta

\footnotetext{
${ }^{17}$ Hengky KV, P. (2013). Perlindungan Pemegang Polis Pada Asuransi Jiwa Di Kaitkan Dengan Nilai Investasi. Jurnal Hukum Unsrat, 1(6), 1-14.

${ }^{18}$ Saraswati, I. A. A., Marwanto, M., \& Dharmakusuma, A. G. A. Kedudukan Hukum Pemegang Polis pada Perusahaan Asuransi yang Dinyatakan Pailit. Kertha Semaya: Journal Ilmu Hukum, 7(7), 1-14.

${ }^{19}$ Solaiman, A. A. (2018). Perlindungan Hukum Pembeli Polis Asuransi Online. Jurnal HUKUM BISNIS, 2(2), 52-66.

20 Soekanto, S. (2010). Pengantar Penelitian Hukum. Jakarta : UII Press, h. 201.
} 
melakukan analisis terhadap peraturan hukum terkait untuk memberikan jawab atas permasalahan yang dirumuskan.

\section{Hasil dan Pembahasan}

\subsection{Pengaturan Lembaga Penjamin Polis pada Perusahaan Asuransi di Indonesia}

Asuransi diambil dari kata assurantie dalam bahasa Belanda. Berdasarkan Hukum Belanda tidak jarang dipergunakan istilah ini dengan verzekering yang berarti pertanggungan. Adanya kata assurantie ini selanjutnya menimbulkan istilah baru yaitu terdapat kata assuradeur yang berarti penanggung serta geassureerde yang artinya tertanggung. Istilah verzekering ini kemudian muncul kata verzekeraar untuk penanggung serta verzekerde untuk tertanggung. ${ }^{21}$

Lembaga asuransi berkembang di Indonesia sejak tahun 1816. Samarang Sea adalah perusahaan asuransi pertama di Indonesia, perusahaan tersebut merupakan perusahaan asuransi yang didirikan oleh pemerintah kolonial Belanda. ${ }^{22}$ Dalam waktu yang sama terdapat beberapa perusahaan lainnya dibidang asuransi meliputi, Mercurius, Arjoeno Veritas, Java Sea dan yang adalah kantor cabang pada perusahaan di bidang asuransi yang kantor pusatnya di Inggris, Belanda, serta negara benua Eropa lain. ${ }^{23}$ Perusahaan ini memiliki tujuan untuk memberikan perlindungan bagi risiko orang-orang Belanda dan juga armada laut pengangkut rempah-rempah. ${ }^{24}$

Kitab Undang-Undang Hukum Dagang (KUHD) juga mengatur mengenai asuransi atau pertanggungan dalam Pasal 246 yang menyebut bahwa pada intinya asuransi yaitu perjanjian antara penanggung yang mengikatkan diri pada tertanggung dengan menerima premi untuk memberi ganti rugi atas rusak ataupun hilangnya keuntungan yang kemungkinan dihadapi karena suatu peristiwa tidak pasti atau evenemen.

Selain itu Undang-Undang Republik Indonesia Nomor 2 Tahun 1992 tentang Usaha Perasuransian mengatur pada intinya asuransi merupakan perjanjian dua pihak atau lebih, yang mana pihak yang yang menanggung mengikatkan diri pada pihak yang ditanggung melalui penerimaan premi asuransi untuk memberi penggantian pada pihak yang ditanggung karena terjadinya kerugian, kerusakan, atau kehilangan keuntungan yang diharapkan, atau tanggung jawab hukum pada pihak ketiga yang mungkin diderita pihak yang ditanggung yang timbul dari suatu peristiwa yang tidak pasti atau untuk memberi suatu pembayaran yang didasari atas meninggal atau hidupnya seseorang yang diberikan tanggungan. ${ }^{25}$ Selanjutnya aturan ini dicabut dan digantikan dengan Undang-Undang Nomor 40 Tahun 2014 tentang Perasuransian (UU Perasuransian) yang menyebutkan definisi asuransi merupakan perjanjian oleh dua pihak, yakni perusahaan asuransi serta pemegang polis, yang mendasari diterimanya

\footnotetext{
21 Ibid.

22 Setiawati, N. S. (2018). Perlindungan hukum terhadap pemegang polis asuransi dalam menyelesaikan sengketa klaim asuransi. Jurnal SPEKTRUM HUKUM, 15(1), h. 151

${ }^{23} \mathrm{Ibid}$.

24 Ibid.

${ }^{25}$ Sulistyorini, H., Hamidah, S., \& Sulistyarini, R. (2020). Perlindungan Hukum Bagi Ahli Waris yang Tidak Tercantum sebagai Penerima Manfaat dalam Asuransi Jiwa. Jurnal Ilmiah Pendidikan Pancasila dan Kewarganegaraan, 5(1), 58-65.
} 
premi oleh perusahaan asuransi sebagai imbalan untuk memberi penggantian pada pihak yang ditanggung atau pemegang polis diakibatkan oleh kerugian, kerusakan, biaya yang timbul, kehilangan keuntungan, atau tanggung jawab hukum pada pihak ketiga karena terjadinya evenemen dan memberi pembayaran yang berdasar pada meninggalnya maupun hidup dari pihak yang ditanggung

Pada intinya perusahaan di bidang perasuransian merupakan perusahaan dengan badan hukum perseroan. Perseroan tidak mampu melakukan tindakan sendiri dalam menjalankan aktivitas selaras dengan tujuan serta maksud dibuatnya suatu perseroan, sehingga dibuatlah organ perseroan sesuai dengan amanat undang-undang. ${ }^{26}$

Berdasarkan penjelasan dari KUHD dan UU Perasuransian, sehingga dapat diketahui bahwa asuransi mengandung empat unsur diantaranya yaitu ${ }^{27}$ Insured yang artinya memberikan janji untuk membayarkan premi pada pihak yang akan menanggung secara sekaligus atau terbagi pada waktu tertentu (pihak peserta), Insurer yang artinya memberikan janji akan memberikan sejumlah santunan pada pihak peserta, sekaligus atau atau terbagi pada waktu tertentu jika terjadi peristiwa yang tidak tentu (pihak penanggung). Accident yang artinya tidak diketahui sebelumnya atau tidak tentu (suatu peristiwa) dan Interest yang artinya memiliki kemungkinan akan mengalami kerugian diakibatkan terjadinya peristiwa yang tidak tentu (kepentingan).

Usaha asuransi memiliki ruang lingkup yakni usaha jasa keuangan dengan mengumpulkan dana masyarakat melalui pengumpulan premi asuransi, melindungi seluruh masyarakat yang mempergunakan jasa asuransi bagi adanya hal yang mungkin terjadinya kerugian diakibatkan terjadinya peristiwa yang tidak pasti pada hidup ataupun meninggalnya seseorang. ${ }^{28}$ Hak dan kewajiban antara penanggung dan tertanggung muncul ketika dilakukan penutupan asuransi meskipun belum di terbitkannya polis. ${ }^{29}$ Asuransi yang ditutup secara praktek dengan bukti penyetujuan aplikasi atau dilakukan penandatanganan kontrak sementara (cover note) yang dibayarnya premi. ${ }^{30}$ Kemudian dalam Pasal 255 KUHD penanggung atau perusahaan asuransi wajib menerbitkan polis asuransi. Polis asuransi sendiri yaitu berkas yang isinya berupa kesepakatan antara pihak tertanggung dan penanggung (pihak asuransi) berkaitan dengan risiko yang ingin dipertanggungkan. ${ }^{31}$

Perjanjian asuransi seperti perjanjian lainnya diberlakukan beberapa prinsip umum hukum perjanjian. Selain prinsip umum hukum perjanjian, juga berlaku beberapa prinsip pada perjanjian dibidang asuransi yaitu prinsip indemnity, insurable interest, prinsip subrogasi, prinsip keterbukaan, prinsip kontrak bersyarat dan prinsip good

\footnotetext{
${ }^{26}$ Sinaga, Syamsudin M. (2012). Hukum Kepailitan Indonesia. Jakarta: Tatanusa, h. 145.

${ }^{27}$ Wulansari, R. (2017). Pemaknaan Prinsip Kepentingan Dalam Hukum Asuransi di Indonesia. Jurnal Panorama Hukum, 2(1), 103-116.

${ }^{28}$ Ridlwan, A. A. (2016). Asuransi Perspektif Hukum Islam. Jurnal Hukum Dan Ekonomi Syariah, 4, 77

${ }^{29}$ Guntara, D. (2016). Asuransi Dan Ketentuan-Ketentuan Hukum Yang Mengaturnya. Justisi Jurnal Ilmu Hukum, 1(1). h. 33

30 Ibid.

${ }^{31}$ Riau, J. I. H. Pemegang Polis Asuransi dan Kedudukan Hukumnya. Op.cit. h. 9.
} 
faith. ${ }^{32}$ Dalam prinsip indemnity, perjanjian dalam hal asuransi bertujuan untuk yaitu melakukan pembayaran ganti kerugian apabila terjadinya risiko terhadap objek yang telah terjamin asuransi itu. Prinsip ini tersirat pada Pasal $246 \mathrm{KUH}$ Perdata yang menyebutkan pada intinya untuk memberikan penggantian terhadap kerugian yang menimpa pihak tertanggung, kerusakan ataupun kehilangan terhadap keuntungan yang mungkin akan dideritanya karena suatu evenemen. Prinsip ini berlaku hanya terhadap asuransi yang keperluannya dapat diukur dengan materi (uang), yakni asuransi kerugian. Insurable Interest mengatur bahwa objek yang dijadikan sebagai asuransi wajib merupakan suatu keperluan yang dapat diasuransikan (insurable interest) agar suatu perjanjian dibidang asuransi dapat dilakukan, atau dapat diukur dengan materi (uang). Hal ini tercermin pada Pasal 250 KUH Perdata yang menyebutkan, penanggung tidak harus memberi ganti kerugian terhadap barang yang ditanggung, jika tertanggung tidak memiliki keperluan pada barang yang dipertanggungkan. Pada Prinsip Subrogasi, jika dengan keterangan apapun bagi objek yang sama, pihak yang ditanggung mendapatkan pula ganti kerugian dari pihak ketiga maka prinsipnya tertanggung tidak boleh mendapatkan ganti kerugian dua kali, untuk itu ganti kerugian oleh pihak ketiga itu menjadi milik penanggung. Tertanggung juga wajib memberikan tanggung jawabnya apabila pihak yang ditanggung melaksanakan tindakan yang mampu memperlambat pihak yang ditanggung dalam mendapatkan hak dari pihak ketiga itu. Hal tersebut dapat disimpangi apabila disebut dengan jelas pada perjanjian asuransi. Prinsip Keterbukaan, tertanggung wajib beritikad baik dengan terbuka secara penuh, maksudnya adalah harus membuka segala hal yang berkaitan dengan objek yang dilakukan pengansuransian. Apabila terdapat data yang tidak benar oleh tertanggung atau pihak tertanggung tidak terbuka padahal data tersebut sangat penting apabila tertanggung diketahui sebelumnya, penanggung memiliki hak untuk tidak memberikan jaminan, walaupun tertanggung mempunyai itikad baik. Hal inilah yang menyebabkan perjanjian asuransi dibatalkan. Menurut prinsip kontrak bersyarat, asuransi adalah perjanjian bersyarat. Perjanjian pada asuransi wajib ditentukan syarat yaitu apabila terjadi evenemen maka uang ganti kerugian akan dibayarkan oleh penanggung. Apabila tidak terjadinya evemenen maka ganti kerugian tidak diberikan. Yang terakhir dalam Prinsip Good Faith ditegaskan bahwa pada perjanjian asuransi baik penanggung maupun tertanggung wajib mengikatkan diri berdasarkan itikad baik. Aturan Pasal 251 KUHD tertanggung bertanggung jawab untuk memberikan keterangan yang benar adalah bentuk dari prinsip itikad baik.

Pasal 52 ayat (1) UU Perasuransian juga menegaskan jika pihak yang ditanggung oleh penanggung atas pembagian kekayaan perusahaan asuransi yang di pailitkan atau di likuidasi memiliki posisi yang lebih tinggi (utama dari hak kreditor lainnya). Lembaga asuransi memiliki kewajiban untuk melakukan penggantian terhadap kerugian pihak tertanggung, lain daripada itu pihak tertanggung memiliki kewajiban pada pihak penanggung untuk membayarkan premi. ${ }^{33}$ Premi adalah kriteria yang mutlak pada

32 Pawitri, R.N. (2018). Kedudukan dan Perlindungan Hukum Pemegang Polis Pada Perusahaan Asuransi yang Pailit Berdasarkan Undang-Undang Nomor 40 Tahun 2014 Tentang Perasuransian. Wacana Hukum, 23(1). h. 43-44.

${ }^{33}$ Laksono, J. T. (2018). Perlindungan Hukum Pemegang Polis Asuransi terhadap Kendaraan Bermotor dalam Angkutan Penyeberangan. Jurnal Hukum Magnum Opus, 1(1). h. 29. 
suatu perjanjian asuransi. Apabila pihak tertanggung telah membayarkan premi, maka saat itu juga risiko kerugian dialihkan pada penanggung. ${ }^{34}$

Ketentuan polis mencantumkan segala bahaya yang akan diberikan pertanggungan oleh penanggung, apabila terdapat kerugian yang disebabkan oleh bahaya yang ada pada polis, maka selanjutnya tertanggung memiliki hak untuk melakukan pengajuan ganti kerugian pada perusahaan asuransi yang telah dipercaya sebagaimana perjanjian yang sudah sepakat dan tertera pada polis. ${ }^{35}$ Seperti contoh terjadi suatu peristiwa, kemudian peristiwa yang dihadapi tertanggung yaitu objek yang ditanggung ada dalam angkutan penyeberangan saat dalam perjalanan terjadilah suatu kecelakaan yang akibatnya objek dari asuransi itu hilang serta mengalami kerugian karena pengangkutan. ${ }^{36}$ Selanjutnya pihak tertanggung memiliki untuk melakukan pengajuan ganti rugi pada pihak perusahaan asuransi, serta pada angkutan penyeberangan itu bertanggung jawab pada barang yang diangkutnya. ${ }^{37}$

Berkaitan mengenai tanggung jawab perusahaan asuransi lebih lanjut dibahas pada Pasal 31 UU Perasuransian yang pada intinya seluruh bagian dari lembaga asuransi wajib untuk melaksanakan seluruh keahlian, perhatian, serta kecermatan saat melayani nasabah, tidak memberikan informasi yang menyesatkan, menangani klaim nasabah dengan baik dan pengaturan lebih lanjut secara spesifik dijelaskan dalam Peraturan Otoritas Jasa Keuangan. ${ }^{38}$

Perjalanan perusahaan asuransi tentu tidak berjalan mulus-mulus saja, dalam beberapa situasi akan terjadi pengaduan dari konsumen asuransi dari perusahaan tersebut. Namun, tidak selamanya perusahaan asuransi yang melakukan kesalahan bagi konsumen. Nasabah perusahaan asuransi juga memiliki celah untuk berlaku curang. Contohnya dengan mengatakan fakta yang salah atau misrepresentation yang selanjutnya akan mempengaruhi keputusan penanggung terhadap penentuan besaran premi. Sehingga terkait perselisihan dibidang asuransi ditegaskan pada UndangUndang Nomor 8 Tahun 1999 tentang Perlindungan Konsumen (UU Perlindungan Konsumen) sebagai sebuat aturan yuridis formal untuk memberikan respon segala perselisihan dan mekanisme penyelesaian permasalahan dibidang asuransi.

Kerugian yang dialami konsumen di bidang asuransi, maka UU Perlindungan Konsumen telah mewadahi keperluan konsumen perusahaan asuransi melalui pemberian pengaturan tentang hak-hak konsumen perusahaan asuransi sebagaimana yang tercantum pada Pasal 4 UU Perlindungan Konsumen meliputi, kenyamanan, keamanan, dan keselamatan dalam mengonsumsi barang dan/atau jasa; memilih barang dan/atau jasa serta mendapatkan barang dan/atau jasa tersebut sesuai dengan perjanjian; informasi yang benar, jelas, dan jujur sebagaimana perjanjian; didengar pendapat dan keluhannya atas barang dan/atau jasa yang dipergunakan; mendapat dengan patut perlindungan serta penyelesaian permasalahannya; mendapat

\footnotetext{
34 Ibid.

${ }^{35} \mathrm{Ibid}$.

${ }^{36}$ Ibid. h. 29-30.

37 Ibid.

${ }^{38}$ Alfi, M., Susilowati, E., \& Mahmudah, S. (2017). Kewenangan Otoritas Jasa Keuangan Dalam Perkara Kepailitan Perusahaan Asuransi. Diponegoro Law Journal, 6(1), 1-9.
} 
pembinaan serta pendidikan konsumen; diperlakukan atau dilayani dengan benar dan jujur serta tidak bersifat diskriminasi; mendapat penggantian, jika barang dan/atau jasa yang didapatkan tidak sama dengan kesepakatan yang telah dilakukan; serta hakhak yang diatur melalui ketentuan peraturan perundang-undangan lainnya.

Banyaknya hak yang diberikan tidak berpengaruh terhadap kasus yang terjadi, masih saja terdapat kasus mengenai gagalnya nasabah dalam mengklaim asuransi yang nasabah miliki. Beberapa kasus diantaranya yaitu pertama, kasus yaitu kasus Grup Bakrie yang gagal membayarkan atas produk Diamond Investa Bakrie Life, tahun 2010 Bakrie Life gagal membayarkan dengan alasan terkena imbas krisis moneter tahun 2008. ${ }^{39}$ Kedua, kasus PT Bumi Asih Jaya, Otoritas Jasa Keuangan pada 2013 mencabut ijin usahanya karena dianggap gagal memenuhi aturan mengenai kesehatan keuangan yaitu rasio solvabilitas dan rasio perimbangan investasi terhadap cadangan teknis dan utang klaim. ${ }^{40}$

Peristiwa gagalnya perusahaan membayarkan prestasinya dapat terjadi karena adanya kesalahan saat menghitung cadangan. Kesalahan ini akan terus bertambah besar yang secara otomatis akan mengakibatkan kewajiban perusahaan menjadi lebih besar dari asset yang dimiliki. Pembuat regulasi mengalami masalah dalam bertindak karena menjadi suatu hal yang membingungkan. Permasalahannya, dalam perusahaan asuransi tidak terdapat Lembaga Penjamin Polis seperti halnya yang ada dalam dunia perbankan yang memiliki Lembaga Penjamin Simpanan (LPS). Apabila perusahaan asuransi di tutup maka tidak akan terdapat dana untuk menggantikan hak bagi setiap pemegang polis. Saat ini Indonesia hanya memiliki perusahaan reasuransi yang saat ini belum efektif untuk melakukan pertanggungan terhadap polis asuransi nasabah sehingga apabila LPP tidak dibentuk maka tidak ada penjamin bagi polis nasabah jika perusahaan asuransi tersebut bangkrut.

\subsection{Dampak dari Tidak Adanya Lembaga Penjamin Polis pada Perusahaan Asuransi di Indonesia}

Tidak terdapatnya Lembaga Penjamin Polis tentunya akan menimbulkan rasa tidak percaya masyarakat pada perusahaan asuransi, terlebih masih adanya permasalahan perihal gagal bayar klaim kepada nasabah perushaan asuransi. Peristiwa gagal bayar ini tentu saja akan berlawanan dengan hak yang seharusnya didapatkan oleh nasabah perusahaan asuransi berdasarkan UU Perlindungan Konsumen yakni berupa hak untuk mendapat perlindungan, advokasi, dan upaya penyelesaian sengketa perlindungan konsumen secara sebagaimana yang seharusnya. Lembaga Penjamin Polis selanjutnya akan mampu meminimalisir kerugian pemegang polis serta memberikan keringanan pemerintah atau pembuat regulasi dalam hal ini Otoritas Jasa Keuangan jika terdapat perusahaan asuransi yang mengalami masalah. ${ }^{41}$ Selaras halnya dengan Lembaga Penjamin Simpanan yang memberikan jaminan dana nasabah perbankan tetap aman apabila bank tersebut terjadi masalah.

39 Anonim. (2019). https://keuangan.kontan.co.id/news/inilah-4-kasus-gagal-bayar-besarasuransi-jiwa-di-indonesia?page=all. Diakses pada 21 Agustus 2020.

40 Ibid.

${ }^{41}$ Togar Pasaribu dalam https://investor.id/finance/lembaga-penjamin-polis-urgen-dibentuktahun-ini. Diakses pada 21 Agustus 2020. 
Belum terbentuknya pengaturan pembentukan Lembaga Penjamin Polis ini tentu saja menyebabkan kasus-kasus mengenai gagal bayar klaim juga tidak kunjung berakhir. Perlindungan bagi pemegang polis asuransi secara yuridis formal sangatlah penting, hal tersebut dikarenakan polis merupan alat bukti tertulis satu-satunya untuk memberikan bukti bahwa asuransi itu telah terlaksana. ${ }^{42}$ Sebagai bukti adanya perjanjian asuransi, polis asuransi bersifat mengikat, melalui polis asuransi telah membuktikan terjadinya proses perpindahan resiko pada perusahaan asuransi misalnya asuransi jiwa ataupun asuransi kerugian. ${ }^{43}$

Perjanjian asuransi merupakan bukti terjadinya hubungan hubungan secara yuridis antara pemegang polis dengan perusahaan asuransi, bisa saja saat proses pemberian tanda tangan perjanjian asuransi, terdapat klausula baku dalam perjanjian yang memberikan tempat pemegang polis pada tempat yang tidak seimbang terlampau lemah. ${ }^{44}$ Sejak penandatanganan perjanjian asuransi telah tertera perjanjian baku, istilah lainnya yaitu kontrak baku yang memiliki potensi menyebabkan kerugian, serta ditambah dengan implementasi dari substansi perjanjian asuransi yang tidak dapat dikatakan mudah bahkan lebih dipersulit, sehingga posisi pemegang polis menjadi lemah dan tidak berdaya. ${ }^{45}$ Pelanggaran oleh pihak perusahaan asuransi terhadap pemenuhan klaim asuransi termasuk sebagai bagian dari lingkup sengketa konsumen atau akibat hukum yang akan terjadi jika terjadinya suatu pelanggaran. Dengan merujuk pada stakeholder teori, maka kedudukan pemegang polis dalam perlindungan hukum adalah pihak yang oleh ketentuan peraturan perundangundangan lebih diberikan perhatian dibanding dengan perusahaan asuransi, sehingga berdasarkan prinsip dalam stakeholder teori maka pemegang polis adalah pihak yang diutamakan kepentingannya dan peristiwa gagal bayar dapat diminimalisir.

Dari sisi teoritis, masalah mengenai finansial perusahaan asuransi diawali oleh aturan asuransi sebagai wadah dalam berbagi risiko (risk sharing). ${ }^{46}$ Anggota perusahaan asuransi dapat melakukan pengalihan beban risiko pada lembaga asuransi dengan pembayaran premi. Ketika risiko terjadi secara nyata, maka pemegang polis asuransi dapat melakukan klaim terhadap uang pertanggungan. ${ }^{47}$ Tanpa adanya jasa asuransi, nasabah harus membiayai risikonya secara pribadi. Kalkulasikan biaya untuk membiayai risiko yang dijalani pasti lebih besar dari kemampuan finansialnya. Apabila klaim nasabah lebih dari premi yang telah dihimpun, perusahaan asuransi wajib untuk mencari sumber pembiayaan lain. Selanjutnya perusahaan asuransi akan mengalokasikan dananya pada berbagai instrument portofolio untuk mendapatkan imbal hasil. Semakin besar investasi yang dialokasikan, maka semakin meningkat juga ekspektasi pendapatannya.

\footnotetext{
${ }^{42}$ Husain, F. (2016). Perlindungan Hukum terhadap Pemegang Polis Asuransi Menurut UU No. 40 Tahun 2014 Tentang Perasuransian. Lex Crimen, 5(6). h. 48.

${ }^{43} \mathrm{Ibid}$.

${ }^{44}$ Ibid. h. 49

45 Ibid.

${ }^{46}$ Kuncoro, Haryo. (2020). https://www.medcom.id/ekonomi/analisis-ekonomi/ObzAQy9Nmenakar-fungsi-pengawasan-ojk. (Diakses pada 26 Agustus 2020).

47 Ibid.
} 
Untuk itu penting dibentuk suatu Lembaga Penjamin Polis (LPP). Sebagaimana yang diarahkan Pasal 53 ayat (1) UU Perasuransian yang menegaskan perusahaan asuransi maupun perusahaan asuransi syariah harus masuk sebagai peserta program penjaminan polis. Selain itu berdasarkan undang-undang tersebut pendirian LPP seharusnya paling lambat tiga tahun setelah undang-undang tersebut diundangkan pada Oktober 2014 lalu. Pada kenyataannya hingga saat ini LPP belum juga terbentuk. Dengan tidak dibentuknya LPP ini maka secara tidak langsung pemerintah tidak menjalankan isi dari undang-undang tersebut. Dibentuknya LPP ini tentu saja akan meningkatkan kepercayaan masyarakat pada perusahaan asuransi. Hal ini akan berkorelasi dengan peningkatan penetrasi asuransi, sehingga masyarakat tidak akan ragu dalam berasuransi karena telah ada yang menjamin. Pembentukan LPP ini tentu saja selanjutnya harus memiliki kriteria perusahaan yang layak menjadi perserta LPP sehingga tidak akan menjadi beban bagi industri asuransi dan dana nasabah juga aman. Beberapa hal yang mesti dipertimbangkan pemerintah dalam pembentukan LPP ini selain kriteria perusahaan yang layak menjadi anggota LPP adalah dibuatnya batasan pertanggungan yang diberikan jaminan dari LPP.48 LPP memiliki peran yang sangat penting dalam penjaminan polis asuransi bagi para pemilik polis, dengan dibentuknya LPP maka dapat memberikan kepastian hukum bagi para pemegang polis yang mana polis yang dimiliki nasabah akan terjamin seperti LPS yang memberikan penjaminan sampai dengan dua miliar rupiah. ${ }^{49} \mathrm{Hal}$ yang menjadi permasalahan lebih lanjut adalah munculnya ketidakadilan dalam penjaminan bagi masyarakat akibat tidak kunjung dibentuknya LPP.

\section{Kesimpulan}

Pengaturan lembaga penjamin polis (LPP) sebenarnya telah tertera pada UndangUndang Nomor 40 Tahun 2014 tentang Perasuransian, akan tetapi sampai saat ini LPP ini belum terbentuk dan belum ada pengaturan tentang LPP. Di Indonesia saat ini hanya memiliki perusahaan reasuransi namun reasuransi tersebut tidak sepenuhnya memberikan pertanggungan kepada nasabah yang memiliki polis asuransi karena reasuransi hanya dapaet mengembalikan 30\% pertanggugan kepada nasabah. Tidak efektifnya perusahaan reasuransi dan tidak terdapatnya LPP tentunya akan menimbulkan tidak percayanya masyarakat pada perusahaan asuransi. Secara otomatis berbagai permasalahan mengenai gagal bayar klaim juga tidak kunjung berakhir. Untuk itu penting dilakukan pengaturan terhadap pembentukan LPP yang didalamnya memuat kriteria perusahaan yang layak menjadi perserta LPP dan batasan pertanggungan yang dijamin oleh LPP tersebut.

\section{Daftar Pustaka}

\section{Buku}

Ganie, A. Junaedy. (2011). Hukum Asuransi Indonesia. Jakarta: Sinar Grafika.

Ridlwan, A. A. (2016). Asuransi Perspektif Hukum Islam. Jurnal Hukum Dan Ekonomi Syariah, 4.

Sinaga, Syamsudin M. (2012). Hukum Kepailitan Indonesia. Jakarta: Tatanusa.

\footnotetext{
48 Putri Anetta Komarudin dalam http://www.dpr.go.id/berita/detail/id/28790/t/Pembentukan+Lembaga+Penjamin+Polis+ Asuransi+Perlu+Dipercepat. Diakses pada 26 Agustus 2020.

49 Ibid.
} 
Soekanto, S. (2010). Pengantar Penelitian Hukum. Jakarta : UII Press.

\section{Jurnal}

Alfi, M., Susilowati, E., \& Mahmudah, S. (2017). Kewenangan Otoritas Jasa Keuangan Dalam Perkara Kepailitan Perusahaan Asuransi. Diponegoro Law Journal, 6(1), 19.

Guntara, D. (2016). Asuransi Dan Ketentuan-Ketentuan Hukum Yang Mengaturnya. Justisi Jurnal Ilmu Hukum, 1(1).

Hengky KV, P. (2013). Perlindungan Pemegang Polis Pada Asuransi Jiwa Di Kaitkan Dengan Nilai Investasi. Jurnal Hukum Unsrat, 1(6), 1.

Husain, F. (2016). Perlindungan Hukum terhadap Pemegang Polis Asuransi Menurut UU No. 40 Tahun 2014 Tentang Perasuransian. Lex Crimen, 5(6).

Laksono, J. T. (2018). Perlindungan Hukum Pemegang Polis Asuransi terhadap Kendaraan Bermotor dalam Angkutan Penyeberangan. Jurnal Hukum Magnum Opus, 1(1).

Pawitri, R.N. (2018). Kedudukan dan Perlindungan Hukum Pemegang Polis Pada Perusahaan Asuransi yang Pailit Berdasarkan Undang-Undang Nomor 40 Tahun 2014 Tentang Perasuransian. Wacana Hukum, 23(1).

Pratama, A. A., \& Bambang Eko Turisno, S. (2017). Perlindungan Hukum Bagi Konsumen Terhadap Perjanjian Perpanjangan Asuransi Melalui Telemarketing. Diponegoro Law Journal, 6(1), 1-21

Riau, J. I. H. Pemegang Polis Asuransi dan Kedudukan Hukumnya. Jurnal Ilmu Hukum Riau, 2(02).

Saraswati, I. A. A., Marwanto, M., \& Dharmakusuma, A. G. A. Kedudukan Hukum Pemegang Polis pada Perusahaan Asuransi yang Dinyatakan Pailit. Kertha Semaya: Journal Ilmu Hukum, 7(7), 1-14.

Setiawati, N. S. (2018). Perlindungan hukum terhadap pemegang polis asuransi dalam menyelesaikan sengketa klaim asuransi. Jurnal SPEKTRUM HUKUM, 15(1).

Solaiman, A. A. (2018). Perlindungan Hukum Pembeli Polis Asuransi Online. Jurnal HUKUM BISNIS, 2(2), 52-66.

Sulistyorini, H., Hamidah, S., \& Sulistyarini, R. (2020). Perlindungan Hukum Bagi Ahli Waris yang Tidak Tercantum sebagai Penerima Manfaat dalam Asuransi Jiwa. Jurnal Ilmiah Pendidikan Pancasila dan Kewarganegaraan, 5(1), 58-65.

Wasita, A. (2020). Perlindungan Hukum Terhadap Pemegang Polis Asuransi Jiwa. Business Economic, Communication, and Social Sciences (BECOSS) Journal, 2(1), 105-113.

Wulansari, R. (2017). Pemaknaan Prinsip Kepentingan Dalam Hukum Asuransi di Indonesia. Jurnal Panorama Hukum, 2(1), 103-116.

\section{Website}

Anonim. (2019). https://keuangan.kontan.co.id/news/inilah-4-kasus-gagal-bayarbesar-asuransi-jiwa-di-indonesia?page=all. (Diakses pada 21 Agustus 2020).

Anonim. (2020). https://investor.id/finance/lembaga-penjamin-polis-urgen-dibentuktahun-ini. (Diakses pada 21 Agustus 2020).

Anonim.(2020).http://www.dpr.go.id/berita/detail/id/28790/t/Pembentukan+Lem baga+Penjamin+Polis+Asuransi+Perlu+Dipercepat. (Diakses pada 26 Agustus 2020).

Asuransi, Aca. https://www.aca.co.id/Berita-Detail/Apa-sih-Reasuransi-itu (Diakses Jumat 18 Agustus 2020) 
Kuncoro, Haryo. (2020). https://www.medcom.id/ekonomi/analisisekonomi/ObzAQy9N-menakar-fungsi-pengawasan-ojk. (Diakses pada 26 Agustus 2020).

Pratama,

Wibi

Pangestu.

https://finansial.bisnis.com/read/20200625/215/1257785/pandemi-covid-19jumlah-tertanggung-naik-kinerja-bisnis-asuransi-tertekan. (Diakses Selasa, 11 Agustus 2020).

Pratama,

Wibi

Pangestu.

https://finansial.bisnis.com/read/20200713/215/1265044/ruu-lembaga-

penjamin-polis-masuk-renstra-kementerian-keuangan-2020-2024.

(Diakses

Selasa, 11 Agustus 2020).

\section{Peraturan Perundangan}

Kitab Undang-Undang Hukum Dagang

Undang-Undang Republik Indonesia Nomor 2 Tahun 1992 tentang Usaha Perasuransian (LN No. : 13 , TLN No. : 3467)

Undang-Undang Republik Indonesia Nomor 8 Tahun 1999 tentang Perlindungan Konsumen (LN No. : 22 , TLN No. : 3821)

Undang-Undang Republik Indonesia Nomor 40 Tahun 2014 tentang Perasuransian (LN No. : 337, TLN No. : 5618) 